\title{
Adenoid cystic carcinoma of the lacrimal sac: case report
}

\author{
Carcinoma adenóide cístico do saco lacrimal: relato de caso
}

Antonio Ramos ${ }^{1}$, Carmen Del Pozo ${ }^{1}$, Ana Chinchurreta ${ }^{1}$, Fernando García ${ }^{1}$, Mercedes Lorenzo $^{1}$, Saturnino Gismero ${ }^{1}$

\begin{abstract}
Lacrimal sac tumors are rare with a clinical presentation that typically includes obstruction of the lacrimal drainage system and epiphora as the most frequent symptom. Cribriform adenoid cystic carcinoma (ACC) is the most common malignant epithelial tumor of the lacrimal gland and minor salivary glands; however, its occurrence in the lacrimal drainage apparatus is extremely rare. Given the rarity of ACC, definitive diagnosis is almost invariably late conferring a poor prognosis. Herein we report the case of a 41-year-old woman with primary ACC of the lacrimal sac and describe the ophthalmological examination, diagnosis, and multidisciplinary treatment of this rare type of tumor.
\end{abstract}

Keywords: Carcinoma; Adenoid cystic/diagnosis; Lacrimal apparatus diseases; Eye neoplasms

\section{RESUMO}

Tumores do saco lacrimal são raros. A apresentação clínica muitas vezes mostra uma obstrução no sistema de drenagem lacrimal sendo a epífora o sinal mais frequente. Carcinoma adenóide cístico cribriforme (ACC) é o tumor epitelial maligno mais comum da glândula lacrimale glândulas salivares menores, mas a sua ocorrência no aparelho de drenagem lacrimal é extremamente rara. Infelizmente, devido a raridade destes tumores, o diagnóstico preciso é quase sempre atrasado, o que por sua vez leva a um pior prognóstico. Nós relatamos o caso de uma mulher de 41 anos de idade, com ACC primário do saco lacrimal e analisamos o exame oftalmológico, diagnóstico e tratamento multidisciplinar deste tipo de tumor.

Descritores: Carcinoma adenoide cístico/diagnóstico: Carcinoma adenoide cístico/ terapia; Doenças do aparato lacrimal; Neoplasias oculares

\section{INTRODUCTION}

Lacrimal sac tumors are rare with a typically non-specific presentation. As the most common signs of lacrimal sac tumors are epiphora or presence of a mass, the process can be incorrectly diagnosed as dacryostenosis or chronic dacryocystitis (DC) $)^{(1-4)}$. Consequently, definitive diagnosis is delayed leading to worsened prognosis ${ }^{(5)}$.

Adenoid cystic carcinoma (ACC) is an extremely rare form of malignant epithelial neoplasia of the lacrimal sac. However, it is the most common type of malignant epithelial tumor of the lacrimal and minor salivary glands $s^{(6,7)}$. To date, 11 cases of ACC of the lacrimal sac have been reported in literature (Table 1).

We report the case of a 41-year-old woman with a right lacrimal sac ACC with a follow-up duration of 24 months post surgery.

\section{CASE REPORT}

A 41-year-old Caucasian woman presented to our department in August 2012 with a 2-year history of lacrimation and pain affecting the medial canthus of the right eye. The lacrimal drainage system was permeable; however, reflux of mucopurulent material was observed. Dacryocystography (DCG) demonstrated a patent pathway with forced passage of contrast from the lacrimal sac. Tumoral pathology was not suspected, and the patient was diagnosed with dacryocystitis and started on topical and systemic antibiotic treatment accordingly.
In August 2013, the patient was re-attended complaining of pain in the right canthus and mucosanguineous secretions from the lacrimal punctum in response to pressure. A new DCG was performed demonstrating a filling defect in the sac without passage of contrast into the distal duct. Orbital magnetic resonance imaging identified a solid-cystic lesion measuring $17 \times 17 \times 13 \mathrm{~mm}$ in the right lacrimal sac seen extending towards the orbit and infiltrating the extraconal fatty tissue (Figure 1). Right dacryocystectomy was performed following observation of a gelatinous mass infiltrating the lacrimal sac and eroding the surrounding bony structures. Pathologic examination demonstrated ACC with a predominantly cribriform pattern infiltrating the muscle and bone tissue with additional perineural infiltration (Figure 2). In the extension study, no signs of tumor spread were evident. Further intervention with right lateral rhinotomy located the mass to the canthal area. The tumor planes were dissected and an osteotomy was performed from the canthal ligament to the orbital floor. The orbital floor was reconstructed before tension-free closure and approximation of the rhinotomy flap. Pathological examination of the dissected tissues confirmed the existence of ACC. Following surgery, the patient had a favorable clinical course. A multidisciplinary approach was established, and the patient received 33 sessions of radiotherapy with no signs of recurrence observed after a follow-up for 2 years.
Submitted for publication: July 24, 2015

Accepted for publication: November 9, 2015

Department of Ophthalmology, Costa del Sol Hospital, Marbella, Malaga, Spain.
Funding: No specific financial support was available for this study.

Disclosure of potential conflicts of interest: None of the authors have any potential conflict of interest to disclose.

Corresponding author: Antonio Ramos. Department of Ophthalmology. Hospital Costa del Sol. Autovia A-7 Km 187 - Marbella, Málaga 29603 - Spain - E-mail: antoniomirmarbella@hotmail.com 
Table 1. Summary of previously reported clinical cases

\begin{tabular}{|c|c|c|c|c|c|c|c|}
\hline Age & Sex & Side & Presentation & Treatment & Recurrence & Follow-up interval & Author \\
\hline 62 & $\mathrm{~F}$ & Right & $\begin{array}{l}2 \text { years epiphora. Lacrimal sac } \\
\text { mass (without data specification) }\end{array}$ & $\begin{array}{l}\text { Enbloc excision of the tumor with } \\
\text { exenteration of the orbit, radical } \\
\text { maxillectomy, and ethmoidectomy. }\end{array}$ & No & 14 months & L. Miller et al. ${ }^{(8)}$ \\
\hline 57 & $\mathrm{~F}$ & Left & $\begin{array}{c}\text { Epiphora and swelling of the } \\
\text { left lower lid (without data } \\
\text { specification) }\end{array}$ & $\begin{array}{c}\text { Orbital exenteration. Further } \\
\text { treatment: } \mathrm{CT} \text {. }\end{array}$ & $\begin{array}{l}\text { Lung metastases } \\
\text { after } 2 \text { years. }\end{array}$ & $\begin{array}{l}48 \text { months after } \\
\text { which she was lost } \\
\text { to follow-up. }\end{array}$ & C. Kincaid et al. ${ }^{(3)}$ \\
\hline 38 & $\mathrm{~F}$ & Not specified & Not specified & Surgery & No & 60 months & A. Stefanyszyn et al. ${ }^{(1)}$ \\
\hline 51 & $\mathrm{~F}$ & Not specified & Not specified & Not specified & No & 60 months & A. Stefanyszyn et al..$^{(1)}$ \\
\hline 64 & $\mathrm{~F}$ & Not specified & Not specified & Not specified & No & 60 months & A. Stefanyszyn et al. ${ }^{(1)}$ \\
\hline 41 & M & Left & $\begin{array}{l}1 \text { month epiphora and lacrimal } \\
\text { sac mass }\end{array}$ & Surgery and RT & No & 12 months & R. Parnel l et al. ${ }^{(9)}$ \\
\hline 72 & M & Right & $\begin{array}{l}1 \text { year epiphora and lacrimal } \\
\text { sac mass }\end{array}$ & $\begin{array}{c}\text { Orbital exenteration and RT for } \\
\text { pulmonary metastases }\end{array}$ & $\begin{array}{l}\text { Lung metastases } \\
\text { after } 16 \text { years }\end{array}$ & 192 months & DN. Parmar et al. ${ }^{(2)}$ \\
\hline 62 & $\mathrm{~F}$ & Not specified & $\begin{array}{c}\text { Epiphora, epistaxis and nasal } \\
\text { obstruction (without data } \\
\text { specification) }\end{array}$ & Surgery and RT & Not specified & Not specified & O. Choussy et al. ${ }^{(10)}$ \\
\hline 74 & M & Right & $\begin{array}{l}\text { Tearing associated with a } \\
\text { palpable mass in the internal } \\
\text { canthus (without data } \\
\text { specification) }\end{array}$ & Exclusive RT & No & Death at 30 months & A. Montalban et al..$^{(5)}$ \\
\hline 48 & $\mathrm{~F}$ & Not specified & Mass & Globe sparring surgery, RT, and CT & Metastatic disease & Death at 48 months & T. El-Sawy et al.(11) \\
\hline 70 & M & Not specified & Mass & Globe sparring surgery, RT, and CT & No & 6 months & T. El-Sawy et al.(11) \\
\hline
\end{tabular}

$\mathrm{F}=$ female; $\mathrm{M}=$ male; $\mathrm{RT}=$ radiotherapy; $\mathrm{CT}=$ chemotherapy.

\section{DISCUSSION}

Epiphora is the most common clinical sign of lacrimal sac tumors ${ }^{(1-4)}$. These tumors may also present as masses in the canthal area. Sanguineous discharge (spontaneous or on lacrimal sac irrigation), epistaxis, pain, and skin ulceration are all highly suspicious of malignancy.

Pathologically, lacrimal sac tumors can be divided into epithelial tumors, mesenchymal tumors, lymphomatous lesions, melanoma, and neuronal tumors. Inflammatory lesions are not true neoplasms but appear as masses in the lacrimal sac with similar symptoms ${ }^{(1)}$.

The most common malignant tumors affecting the lacrimal sac are of the epithelial type, with squamous subtype having the highest incidence within this group. ACC is an extremely unusual entity in the lacrimal drainage system ${ }^{(1,2,4)}$.

ACC is slow-growing ${ }^{(6,7)}$ but has a tendency for perineural invasion and spread to adjacent tissues, such as the bone ${ }^{(4,8)}$. Local recurrence is frequently observed several years after surgical excision. Although a late finding, hematogenous metastases are possible and ${ }^{(7)}$ most commonly affect the lungs. Local lymph node involvement is rare ${ }^{(5-7)}$.

From a histological standpoint, there are three types of ACC: cribriform, tubular, and solid. Cribriform pattern foci are generally constant even when a different histological tumor type predominates. The cribriform pattern is the most common and associated with the best prognosis, whereas the solid type is less frequent but has a poorer prognosis $^{(3,7,8)}$.

The most appropriate approach to the management of lacrimal sac tumors depends more on the tumoral size and the general condition of the patient rather than the histological type ${ }^{(5)}$. The classical treatment of malignant lacrimal sac tumors has been complete excision of the tumor and lacrimal drainage system, including the canaliculi and nasolacrimal duct, followed by radiotherapy and/or adjuvant chemotherapy ${ }^{(1,9)}$. At present, a multidisciplinary approach to disease treatment is essential in obtaining the best clinical outcomes ${ }^{(11)}$. The need to perform orbital exenteration versus more conservative

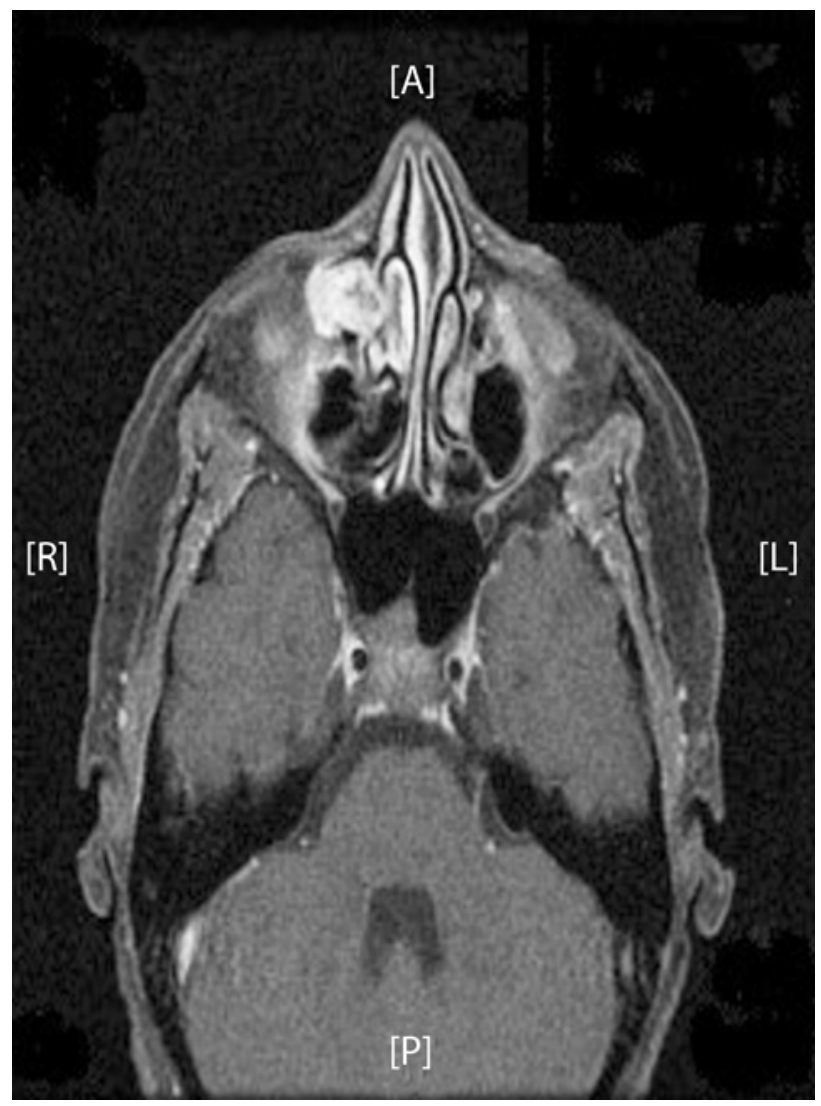

Figure 1. Solid-cystic lesion occupying the right lacrimal sac region consistent with a neoplastic process. 


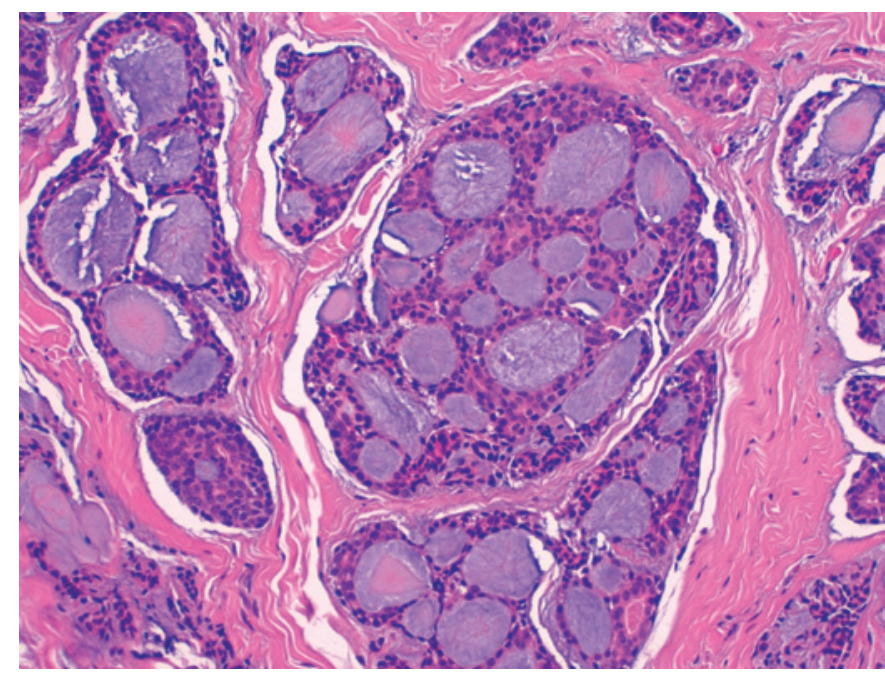

Figure 2. Presence of basophilic mucoid material in pseudocystic areas (hematoxylin-eosin stain, $\times 20$ times magnification).

surgery should always be evaluated individually, as exenteration does not ensure a better prognosis(2) and causes substantial facial disfigurement that may lead to severe psychological and psychiatric disorders.

Following appropriate treatment, patients must undergo lifelong follow-up given the high rate of local recurrence of lacrimal sac tumors ${ }^{(11)}$. Because of the poor specificity of clinical symptoms, clinicians must have a high degree of suspicion to arrive at a prompt definitive diagnosis. Lacrimal sac tumors should be considered in any patient with chronic epiphora or dacryocystitis who does not respond to standard treatments. Radiological studies with DCG, Computed Tomography (CT)-DCG, CT, and magnetic resonance imaging are essential in ruling the possibility of a lacrimal sac tumor ${ }^{(1,5)}$. In any case, pathological examinations are required for a definitive diagnosis of lacrimal sac tumor(4).

\section{CONCLUSION}

Lacrimal sac tumors should be considered in any case of epiphora or dacryocystitis that does not improve with dacryocystorhinostomy. Imaging studies are required to rule out the presence of a lacrimal drainage system tumor.

The finding of a mass or gelatinous tissue during dacryocystorhinostomy may require termination of the procedure or performance of a biopsy and imaging studies to rule out the existence of neoplasia(11).

Ophthalmologists should be aware of the characteristic triad of primary lacrimal sac tumors, which includes the clinical findings of persistent dacryocystitis or epiphora, an irreducible mass, and abnormal dacrycystography. Delayed diagnosis may worsen the prognosis of this rare type of malignant tumor.

\section{REFERENCES}

1. Stefanyszyn MA, Hidayat AA, Jacob J, Flanagan JC. Lacrimal sac tumors. Ophthal Plast Reconstr Surg. 1994;10(3):169-84.

2. Parmar DN, Rose GE. Management of lacrimal sac tumors. Eye (Lond). 2003;17(5): 599-606.

3. Kincaid MC, Meis JM, Lee MW. Adenoid cystic carcinoma of the lacrimal sac. Ophthalmology. 1989;96(11):1655-8.

4. Ni C, D'Amico DJ, Fan CQ, Kuo PK. Tumors of the lacrimal sac: a clinicopathological analysis of 82 cases. Int Ophthalmol Clin. 1982;22(1):121-40.

5. Montalban A, Liétin B, Louvrier C, Russier M, Kemeny JL, Mom T, et al. Malignant lacrimal sac tumors. Eur Ann Otorhinolaryngol Head Neck Dis. 2010;127(5):165-72.

6. Chawla B, Kashyap S, Sen S, Bajaj MS, Pushker N, Gupta K, et al. Clinicopathologic review of epithelial tumors of the lacrimal gland. Ophthal Plast Reconstr Surg. 2013; 29(6):440-5.

7. Lukšić I, Suton P, Macan D, Dinjar K. Intraoral adenoid cystic carcinoma: is the presence of perineural invasion associated with the size of the primary tumor, local extension, surgical margins, distant metastases, and outcome? Br J Oral Maxillofac Surg. 2014;52(3): 214-8.

8. Miller CL, Offutt WN, Kielar RA. Adenoid cystic carcinoma of the antrum and epiphora. Am J Ophthalmol. 1977;83(4):582-6.

9. Parnell JR, Mamalis N, Davis RK, Flaharty PM, Anderson RL. Primary adenoid cystic carcinoma of the lacrimal sac: report of a case. Ophthal Plast Reconstr Surg. 1994;10(2): 124-9.

10. Choussy O, Babin E, Delas B, Bailhache A, François A, Marie JP, et al. Les tumeurs malignes primitives des voies lacrymales. Ann Otolaryngol Chir Cervicofac. 2007; 124(6):309-13.

11. El-Sawy T, Frank SJ, Hanna E, Sniegowski M, Lai SY, Nasser QJ, et al. Multidisciplinary management of lacrimal sac/nasolacrimal duct carcinomas. Ophthal Plast Reconstr Surg. 2013;29(6):454-7.

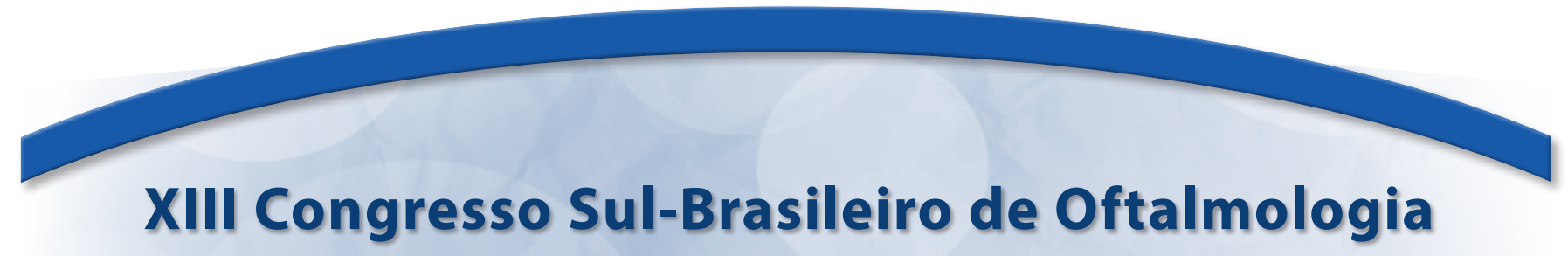

31 de março a $1^{\circ}$ de abril de 2017

Sede da Associação Catarinense de Medicina

Florianópolis - SC

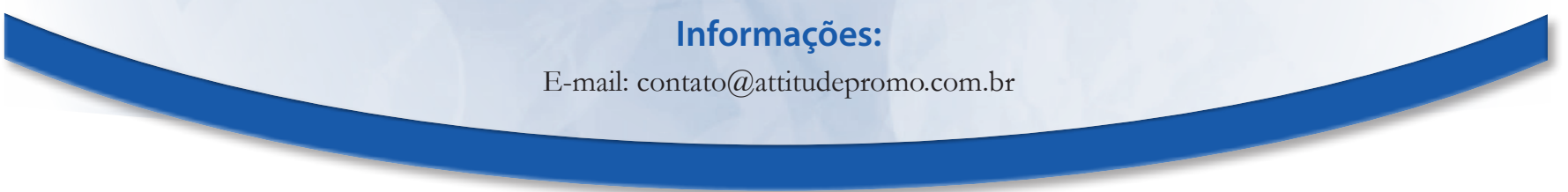

